\title{
p-ISSN 2302-6960 \\ e-ISSN 2716-165X \\ PENGARUH PROFESIONALISME KERJA APARAT TERHADAP KUALIAS PELAYANAN PUBLIK DI KANTOR DESA ANABANNAE KECAMATAN PITU RIAWA KABUPATEN SIDENRENG RAPPANG
}

\author{
1)Erni Nawir, 2)Monalisa Ibrahim, ${ }^{3}$ Hariyanti Hamid \\ Fakultas IImu Sosial dan IImu Politik Universitas Muhammadiyah Sidenreng Rappang \\ erninawir43162123.1a@gmail.com \\ monalisa2231@yahoo.com \\ tantistisip@yahoo.co.id
}

\begin{abstract}
Abstrak
Penelitian ini bertujuan untuk mengetahui Pengeruh Profesionalisme kerja Aparat terhadap kualitas pelayanan publik di kantor Desa Anabannae Kecamatan Pitu Riawa Kabupaten Sidenreng Rappang. Populasi penelitian ini adalah 1.181 orang dan sampel sebanyak 92 orang. Teknik penarikan sampel yang digunakan yaitu random sampling atau sampel acak. Tipe penelitian ini adalah deskriptif kuantitatif. Teknik pengumpulan data adalah observasi, wawancara, penelitian pustaka dan kuesioner. Teknik analisis data menggunakan analisis deskriptif, uji kualitas data (validitas dan reabilitas), uji asumsi klasik, regresi linear dan pengujian hipotesis dan dengan bantuan aplikasi SPSS versi 21. Hasil penelitian menunjukkan bahwa Profesionalisme kerja Aparat $59.6 \%$ kurang baik. kualitas pelayana publik $59.16 \%$ kurang baik. Faktor-faktor yang mempengaruhi profesionalisme kerja $60.32 \%$ kurang baik meliputi kemahiran $31,4 \%$, kesiapan $58,6 \%$, tanggung jawab $60 \%$, disiplinan $61,2 \%$, dan sikap pegawai $60,4 \%$. Hal ini menunjukkan Pengaruh Profesionalisme Kerja Aparat terhadap Kualitas Pelayanan Publik di kantor Desa Anabannae Kecamatan Pitu Riawa adalah 59\% dari 100\% hasil yang diharapkan, dimana ini tergolong dalam kategori "kurang baik".
\end{abstract}

Kata kunci : Profesonalisme dan Kualitas Pelayanan Publik

\begin{abstract}
The aim of this research is to find out the influence of the professionalism of the apparatus work towards the quality of public services in the Anabannae Village office, Pitu Riawa District, Sidenreng Rappang Regency. The population of this study was 1,181 people and a sample of 92 people. The sampling technique used is random sampling. This type of research is quantitative descriptive. Data collection techniques are observation, interviews, library research and questionnaires. Data analysis techniques using descriptive analysis, data quality tests (validity and reliability), classic assumption tests, linear regression and hypothesis testing and with the help of SPSS version 21 application. The results showed that the professionalism of the work apparatus $59.6 \%$ was not good. the quality of public service $59.16 \%$ is not good. Factors that influenced the professionalism of work $60.32 \%$ were unfavorable including $31.4 \%$ proficiency, $58.6 \%$ readiness, $60 \%$ responsibility, $61.2 \%$ discipline, and $60.4 \%$ employee attitude. This shows the Effect of Professional Workers' Apparatuses on the Quality of Public Services at the Anabannae Village Office in Pitu Riawa Subdistrict is $59 \%$ of the $100 \%$ expected results, which are classified as "not good".
\end{abstract}

Keywords: Professionalism and Public Service Quality

PRAJA | Volume 9 | Nomor 1 | Edisi Februari 2021 


\section{A. PENDAHULUAN}

Undang-Undang Republik Indonesia Nomor 25 Tahun 2009 Tentang Pelayanan Publik Pasal 2 berbunyi "Undang-undang tentang pelayanan publik diketehui untuk memberikan suatu kepastian hukum dalam hubungan denganmasyarakat dan penyelenggara dalarn suatu pelayanan publik" pasal 3 "Tujuan undang-undang tentang pelayanan publik adalah; a) terwujudnya sebuah batasan dan hubungan yang jelas mengenai hak, tanggung jawab, kewajiban, dan kewenangan seluruh pihak yang terkait dengan penyelenggaraan pelayanan publik; b) terwujudnya suatu sistem penyelenggaraan tentang pelayanan publik yang layak berdasarkan dengan asasasas umum lembaga pemerintahan dan korporasi yang layak; c) terpenuhinya suatu penyelenggaraan mengenai pelayanan publik bedasarkan dengan peraturan perundangundangan; d) terwujudnya suatu perlindungan dan kepastian hukum bagi masyarakat dalam penyelenggaraan pelayanan publik.

Moenir (Sellang 2016:75) Pelayanan umum adalah suatu kegiatan yang dilaksanakan bagi seseorang atau sekelompok orang berdasarkan landasan faktor material melalui sebuah sistem prosedur dengan metode tertentu dalam upaya memenuhi kepentingan orang lain sesuai dengan haknya. Pelayanan hakikatnya adalah merupakan proses. Suatu sebagai proses pelayanan yang secara rutin dan berkesinambungan, yakni seluruh kehidupan orang dalam masyarakat. Pelayanan publik dapat diukur, berdasarkan yang telah ditetapkan dalam standar yang layak sesuai waktu yang dibutuhkan.

Pelayanan yaitu suatu tugas utama yang mutlak dari aparatur,sebagai abdi negara dan abdi masyarakat. Tugas tersebut tercantum dalam pembukaan UUD 1945 alinea keempat, yang meliputi 4 (empat) aspek pelayanan pokok aparatur terhadap masyarakat, yaitu melindungi segenap bangsa Indonesia dan seluruh tumpah darah Indonesia, memajukan kesejahteraan umum, mencerdaskan kehidupan bangsa dan melaksanakan ketertiban dunia yang berdasarkan kemerdekaan, perdamaian abadi dan keadilan sosial (Crystalia, 2015).

Rendahnya kualitas pelayanan publik yang diberikan dari pegawai menjadi citra buruk pemerintah ditengah masyarakat. Bagi masyarakat yang pernah berurusan dengan birokrasi selalu mengeluh terhadap tidak layaknya pegawai untuk memberikan pelayanan. Pelayanan kepada masyarakat tidak akan bisa terselenggara secara optimal tanpa diseratai kesiapan aparatur pemerintah yang profesional untuk menjalangkan visi dan misi dalam pemerintahan(Nurbaiti, 2013), dilihat dari peyenlenggarannya, dalam pelayanan publik masih terdapat beberapa kelemahan yakni Kurangnya respon, dimana pelayanan publik yang ada di Kantor Desa Anabannae dari aparat desa ditemukan fakta bahwa kemampuan pegawai masih rendah dalam memberikan pelayanan, hal tersebut ditandai dengan tidak adanya standar operasional prosedur sehingga dalam menyelasaikan suau pekerjaan kurang optimal, Kurangnya penyampaian Informasi. Berbagai informasi seharusnya disampaikan kepada masyarakat malah berjalan lambat atau bahkan tidak sampai kepada masyarakat, Rendahnya kualitas birokrasi. Dimana pihak kemungkinan masyarakat untuk bertemu dengan penanggungjawab pelayanan, dalam rangka penyelesaian masalah yang terjadi ketika pelayanan diberikan sangat sulit. Yang mengkibatnya, suatu masalah pelayanan yang membutuhkan waktu yang lama untuk menyelesaikan dengan tepat waktu, Kurang mendengar aspirasi masyarakat. Pada dasarnya aparat pelayanan kurang memiliki kemauan untuk mendengar suatu pendapat dari masyarakat. Akibatnya pelayanan dijalangkan apa adanya, tanpa adanya perbaikan seperti terhentinya pengelolaan program dana pemberdayaan masyarakat sejak tahun 2017 sedangkan anggaran dana BUMDes dan dana program pemberdayaan masyarakat dari pemerintah masih berjalan hingga sekarang, dan Dlihat dari sisi sumber daya manusianya. Kelemahan utamanya yaitu berkenaan pada profesionalisme, kompetensi, dan etika dari latar belakang pendidikan.

Masalah dapat disimpulkan mengenai keahlian harus sesuai dengan bidangnya sehingga mempengaruhi kualitas pelayanan publik atau pelayanan administrasi secara umum karena dipengaruhi oleh profesional kerja aparat yang tidak berkualitas seperti kurangnya respon dalam memberikan pelayanan, kurangnya peyampaian informasi, 
rendahnya kualitas birokrasi, kurang mau mendegar aspirasi masyarakat, dan lemahnya sumber daya manusia. Permasalahan utama bagi pelayanan publik bersangkutan dalam peningkatan kualitas pelayanan tersebut. Pelayanan yang berkualitas sangat bergantung dalam aspek, yakni tata pelaksanaanya, dukungan sumber daya manusia,dan organisasinya. Berdasarkan dari uraian sebelumnya maka peneliti menarik kesimpulan untuk melakukan penelitian dengan judul Pengaruh Profesionalisme Kerja Aparat terhadap Kualitas Pelayanan Publik di Kantor Desa Anabannae Kecamatan Pitu Riawa Kabupaten Sidenreng Rappang dengan tujuan untuk mengetahui Profesionalisme Kerja Aparat terhadap Kualitas Pelayanan Publik di Kantor Desa Anabannae Kecamatan Pitu Riawa Kabupaten Sidenreng Rappang dan untuk mengetahui Faktor-faktor yang Memengaruhi Profesionalisme Kerja Aparat terhadap Kuualiitas Pelayanan Publik di Kantor Desa Anabannae Kecamatan Pitu Riawa Kabupaten Sidenreng Rappang.

Suatu profesi secara teori tidak bisa dilakukan oleh sembarang orang yang tidak dilatih atau disiapkan. Sementara profesional menunjuk pada dua hal, yaitu: 1) menunjuk pada kinerja seseorang yang sesuai dengan tuntutan profesinya; dan 2) menunjuk pada orang yang melakukan pekerjaan (seorang professional). (Ibrahim, 2014).

Sedarmayanti (Karim dkk, 2015) profesionalisme adalah suatu sikap atau keadaan dalam melaksanakan pekerjaan dengan memerlukan keahlian melalui pendidikan dan pelatihan tertentu dan dilakukan sebagai suatu pekerjaan yang menjadi sumber penghasilan. Sedangkan yang dikemukan oleh (Siagian 2000:163), Profesionalisme juga dapat diartikan keandalan dalam pelaksanaan tugas sehingga terlaksana dengan mutu yang baik, waktu yang tepat, cermat dan dengan prosedur yang mudah dipahami dan diikuti oleh pelanggan. Teori yang diungkapkan oleh Menurut Martin Jr dalam Marlin Marianti (2005) profesionalisme aparat.

1. Persamaan (Equality). perlakuan yang sama atas pelayanan yang diberikan. Hal ini didasarkan atas tipe perilaku birokrasi rasional yang secara konsisten memberikan pelayanan yang berkualitas kepada semua pihak tanpa memandang status sosial, politik, dan sebagainya.
p-ISSN 2302-6960

e-ISSN 2716-165X

Bagi mereka memberkan perlakuan yang sama identik dengan belaku jujur.

2. Keadilan (Equity). Keadilan yaitu perlakuan yang samakepada masyarakat tidak cukup, selain itu juga perlakuan adil. Umtuk masyarakat yang pluralistiik kadang-kadang diperlakukan yang sama. Misalnya menghaus diskriminasi pekerjaaan, sekolah, perumahan, dan sebagainya. Serta kadang-kadang pula diperlukan perlakuan yang adil tetapi tidak sama kepada orang tertentu (pemberian kredik tanpa bunga kepada pengusaha lemah).

3. Kedisplinan (Loyality). Kesetiaan diberikan kepada konstitusi, hukum, pimpinan, bawahan dan rekan kerja. Berbagai jenis kesetiaan tersebut terkait satu sama lain dan tidak ada kesetian yang mutlak diberikan kepada satu jenis kesetiaan tertentu dengan mengebaikan yang lainnya.

4. Tanggung jawab (Accountability). Setiap aparat pemerintah harus siap menerima tanggung jawab atas apapun yang ia kerjakan dan harus menghindarkan diri dari sindroman (saya sekedar melaksanakan perintah atasan).

Penyelenggara pelayanan publik adalah setiap institusi penyelenggaraan negara, korporasi, lembaga independen yang dibentuk berdasarkan undang-undang untuk kegiatan pelayanan publik, dan badan hukum lain yang dibentuk semata-mata untuk kegiatan pelayanan publik. Hilangnya kepercayaan masyarakat terhadap penyelenggaraan pelayanan publik akan berakibat rusaknya tatanan hukum dan aturan yang menjadi prasyaratan bagi suatu kedaulatan negara. Peraturan dan keteraturan (rule and order) menjadi modal dasar bagi terbagunnya demokrasi dan keadilan dalam masyarakat (Sellang, 2016 : 76). Lijan Poltak Sinambela (2008:6) mengatakan bahwa untuk mencapai kepuasan itu dituntut kualitas pelayanan prima yang tercermin dari hal-hal sebagai berikut:

1. Transparansi. Pelayanan yang bersifat terbuka, mudah dan dapat diakses oleh semua pihak yang memudahkan dan disediakan secara memadai serta mudah dimengerti.

2. Akuntabilitas. Pelayanan yang dapat dipertanggungjawabkan sesuai dengan 
ketentuan peraturan perundangundangan.

3. Kondisional. Pelayanan yang sesuai dengan kondisi dan kemampuan pemberi dan penerima pelayanan dengan tetap berpegang pada prinsip-prinsip dan efektivitas.

4. Partisipatif. Pelayanan yang dapat mendorong peran serta masyarakat dalam penyelenggara pelayanan publik dengan memperhatikan aspirasi kebutuhan, dan harapan masyarakat.

5. Kesamaan hak. Pelayanan yang tidak melakukan diskriminasi dilihat dari aspek apa pun, status sosial, dan lain-lain.

6. Keseimbangan hak dan kewajiban. Pelayanan yang mempertimbangkan aspek keadilan antara pemberi dan penerima pelayanan adalah kualitas pelayanan birokrat terhadap publik.

Faktor yang perlu dipertimbangan dalam upaya untuk meningkatkan profesionalisme kerja aparatut. Menurut Martin Jr dalam Miftah Thoha (2001:75).

1. Kemahiran. mempergunakan perelatan kemahiran merupakan salah satu unsur kemetagan yang berkaitan denan penetahuan dan keterampilan yan diperoleh dari pendidikan dan pelatihan serta pengelaman.

2. Kesiapan. Kesiapan para pegawai untuk memberikan pelayanan yang dibutuhkan publik. Kemauan memberikan pelayanan yang cepat (responsif) dan tepat kepada masyarakat, dengan penyampaian informasi yang jelas.

3. Tanggung jawab. Pelayanan tuntutan pertanggungjawaban atas setiapa kegiatan yang dilakukan untuk kepentingan publik menjadi penting bagi berlangsungnya sistem pemerintah yang baik berdasarkan kepercayaan.

4. Disiplin. Secara teoritis loyalitas berhubungan dengan tingkat kedisiplinan, terutama dalam hal ketaatan terhadap peraturan yang berlaku.

5. Sikap Pegawai. Setiap orang dalam suatu perusahan memiliki keterampilan, sikap dan pengetahuan yang dibutuhkan agar dapat memberikan pelayanan tertentu..

\section{B. METODE PENELITIAN}

Penelitian ini menggunakan tipe penelitian deskriptif kuantitatif, dengan metode ini diharapkan dapat memberikan gambaran secara cermat, jelas dan objektif mengenai masalah yang sedang diteliti. Populasi dalam penelitian ini adalah seluruh masyarakat di Desa Anabannae dengan jumlah 1.181 orang. Maka, jumlah populasi dalam penelitian ini adalah 1.181 orang. Penarikan sampel dalam penelitian ini yaitu random sampling atau sampel acak. Pada teknik acak ini, secara teoretis, semua anggota dalam populasi mempunyai probabilitas atau kesempatan yang sama untuk dipilih menjadi sampel. Penelitian ini kriteria responden yang ditentukan adalah kepala keluarga yang tinggal di lokasi penelitian, minimal berusia 17-50 tahun yang memahami masalah akuntabilitas pelayanan publik maupun pengelolaan dana desa.

Teknik pengumpulan data, yang meliputi Observasi, Studi Kepustakaan, dan Kuesioner/Angket. Jenis data yang sudah terkumpul, maka dilakukan analisis dengan bantuan tabel frekuensi dan SPSS 21. Nilainilai varian sebagai hasil olahan data akan menggambarkan suatu hubungan antara variabel yang satu dengan variabel lainnya. Data hasil penelitian dianalisis dengan alat statistik yang terdiri dari: Analisis Deskriptif, Uji Kualitas Data (Validitas dan reabilitas), Uji Asumsi Klasik, Regresi Linear sederhana dan Pengujian Hipotesis.

\section{Hasil Penelitian dan Pembahasan}

1. Hasil penelitian Profesionalisme Kerja Aparat (X) a) kemampuan aparat Desa Anababnnae untuk memberikan perlakuan yang sama atas pelayanan yang diberikan kepada masyarakat sebesar $58.8 \%$, b) kemapuan aparat Desa Anabannae untuk memberikan perlakuan yang adil atas pelayanan yang diberikan kepada masyarakat $58 \%$, c) kemampuan aparat Desa Anabannae terhadap Kesetiaan dalam melaksanakan tugas yang diberikan oleh aparat kepada masyarakat $59.4 \%$, d) mengenai tanggung jawab aparat desa dalam melaksanakan tugas di Kantor Desa Anabannae $62.2 \%$. Berdasarkan tabel diatas dapat dijelaskan bahwa masyarakat sebagai responden memberikan tanggapan profesonalisme kerja yaitu $59.6 \%$ atau dikategorikan kurang baik.

2. Hasil penelitian Kuaitas Pelayanan Publik a) sikap keterbukaan yang diperliatkan oleh aparat di Kantor Desa Anabannae kepada masyarakatyang membutuhkan pelayanan $64.4 \%$, b) kemampuan aparat di Kantor Desa Anabannae untuk 
bertanggungjawab terhadap pelayanan yang diberikan kepada seluruh masyarakat $56 \%$, c) kemampuan aparat di Kantor Desa Anabannae untuk memmahami keadaan setiap masyarakat $55.8 \%$, d) kemampuan aparat di Kantor Desa Anabannae untuk mengikutsertakan masyarakat dalam setiap pengambilan keputusan $59.4 \%$, e) kemampuan aparat di Kantor Desa Anabannae untuk berbuat adil kepada masyarakat $62.2 \%$, f) kemampuan aparat di Kantor Desa Anabannae untuk menyimbangkan antara tugas dan kepentingan pribadinya $57.2 \%$. Berdasarkan tabel diatas dapat dijelaskan bahwa masyarakat sebagai responden memberikan tanggapan kualitas pelayanan publik yaitu $59.16 \%$ atau dikategorikan kurang baik.

3. Hasil penelitian faktor-faktor yang memengaruhi profesionalisme kerja aparat 1). Kemahiran : Pengetahuan dan keterampilan yang diperoleh dari pendidikan dan pelatihan serta pengalaman aparat di Kantor Desa Anabannae 31,4\%. 2). Kesiapan : Kemampuan aparat di Kanttor Desa Anabannae dalam memberikan pelayanan yang cepat dan tepat kepada masyarakat $58,6 \%$. 3). Tangggungjawab : Kemampuan aparat di Kantor Desa Anabannae menghubungi masyarakat secepatnya apabila terjadi sesuatu sesuai yang perlu segera diberitahukan 60\%. 4). Kedisplinan : Kemampuan aparat menaati peraturanperaturan yanga ada di Kantor Desa Anabannae 61,2\%. 5). Sikap Pegawai : Pegawai di Knator Desa Anabannae memiliki keterampilan, sikap dan pengetahuan yang dibutuhkan agara dapat memberikan pelayanan $60.4 \%$. Berdasarkan diatas dapat dijelaskan bahwa masyarakat sebagai responden memberikan tanggapan faktor-faktor yang mempengaruhi profesionalisme kerja yaitu $60.32 \%$ atau dikategorikan kurang baik .

Berdasarkan hasil olah data, diketahui bahwa 4 item pertanyaan yang digunakan untuk mengukur variabel profesionalisme $\operatorname{kerja}(\mathrm{X})$ dinyatakan valid dengan nilai corrected item-total correlation $>0.25,0.30$ (corrected item-total correlation> 0.25, 0.30).

Berdasarkan tabel hasil olah data diketahui bahwa 6 item pertanyaan yang digunakan untuk mengukur variabel (kualitas pelayanan publik) dinyatakan valid dengan
p-ISSN 2302-6960

e-ISSN 2716-165X

nilai corrected item-total correlation lebih besar dari $>0.25,0.30$ (corrected item-total correlation> $0.25,0.30$ ).

Hasil olah data diketahui bahwa 5 item pertanyaan yang digunakan untuk mengukur variabel (faktor-faktor yang mempengaruhi profesionalisme kerja) dinyatakan valid dengan nilai corrected item-total correlation lebih besar dari $>0.25,0.30$ (corrected itemtotal correlation> $0.25,0.30$ ). Hasil reliability statistics, kuesioner penelitian yang digunakan untuk mengukur variabel $X$ reliabel atau hAparaturl karena Cronbach Alpha yang diperoleh adalah sebesar 0.618 yang berarti lebih besar dari 0.60 (0.618 > 0.60). Hasil reliability statistics, kuesioner penelitian yang digunakan untuk mengukur variabel $\mathrm{Y}$ reliabel atau hAparaturl karena Cronbach Alpha yang diperoleh adalah sebesar 0.701 yang berarti lebih besar dari $0.60(0.701>0.60)$. Hasil reliability statistics, kuesioner penelitian yang digunakan untuk mengukur variabel $\mathrm{F}$ reliabel atau hAparaturl karena Cronbach Alpha yang diperoleh adalah sebesar 0.826 yang berarti lebih besar dari $0.60(0.826>0.60)$.

Pada bagian output model summary, bagian ini ditampilkan ni $\mathrm{R}=0.710$ dan koefisien Determination Rsquare atau $\left(\mathrm{R}^{2}\right)$ nilai sebesar 0.505 (hasil dari pengkuadratan koefisien korelasi atau (R) $0.710 \times 0.710=$ $0.504 \times 100 \%=50.4 \%)$, sedangkan sisanya $(100 \%-50 \%=49.6 \%)$. Hal ini menunjukkan bahwa untuk mencari besar faktor profesionalisme kerja $(X)$ terhadap kualitas pelayanan publik $(\mathrm{Y})$ dengan ini nilai yang dicari yaitu $49.6 \%$.

Hasil dari uji ANOVA pada bagian ini ditampilkan hasil yang diperoleh adalah nilai $\mathrm{F}=91.652$ dengan tingkat probabilitas sig. 0.000 . Oleh karena probabilitas $(0,000)$ jauh lebih kecil dari 0.05 , maka model regresi bisa dipakai untuk memprediksi profesionalisme kerja. Untuk menguji kebenaran hipotesis dalam penelitian ini dilakukan uji $F$. Untuk mengetahui bahwa pengaruh/Signifikan dapat diketahui dengan melihat dari lefel of signifikan $a=0,05$. Jika nilai signifikan lebih kecil dari 0,05 , maka $\mathrm{HO}$ ditolak dan $\mathrm{Ha}$ diterima. Berdasarkan hasil olah pada tabel ANOVA, maka diketahui nilai Fhitung yang diperoleh sebesar 91.652 dengan tingkat signifikan 0,000 (Sig < 0,05) yang berarti bahwa variabel profesionalisme kerja $(X)$ mempunyai pengaruh/signifikan terhadap kualitas pelayanan publik (Y), dari hasil 
tersebut berarti model regresi dapat digunakan untuk memprediksi kualitas pelayanan publik di Kantor Desa Anabannae Kecamata Pitu Riawa Kabupaten Sidenreng Rappang. Hasil Coefficient olah data, maka model regresi yang digunakan dalam penelitian ini untuk mengukur pengaruh profesioonalisme kerja aparat terhadap kualitas pelayanan publik di Kantor Desa Anabannae Kecamata Pitu Riawa Kabupaten Sidenreng Rappang.

$$
Y=5.452+1.011 X
$$

Dari fungsi regresi di atas, maka dapat dijelaskan :

1. Jika variabel profesionalisme kerja aparat (X) berubah, maka kualitas pelayanan publik (Y) juga akan berubah. Tanda positif menunjukkan perubahan yang searah. Apabila professionalisme kerja aparat meningkat, maka kualitas pelayanan publik juga akan meningkat dengan koefisien regresi sebesar 1.011 dan sebaliknya, jika profesionalisme kerja aparat menurun, maka kualitas pelayanan publik juga akan menurun dengan koefisien regresi sebesar 5.452.

2. Nilai konstanta sebesar 5.452 menunjukkan bahwa, jika semua variabel konstan maka Model profesionalisme kerja aparat masih bersifat positif.

Uji statistic $t$ untuk menunjukkan seberapa jauh pengaruh satu variabel penjelas/independen secara individual menerangkan variasi variabel dependen berdasarkan tabel coefficients hasil olah data SPSS, maka diketahui bahwa :

a. Nilai thitung variabel profesionalisme kerja aparat (X) 1.011 dengan tingkat signifikan 0,000 .

b. Hipotesis berdasarkan uji $t$ dirumuskan secara statistic

$\mathrm{Ha}:$ Pyx $\neq 0$

$\mathrm{HO}: \mathrm{Pyx} \neq 0$

Hipotesis bentuk kalimat :

1. $\mathrm{Ha}$ : profesionalisme kerja aparat berpengaruh/signifikan terhadap kualitas pelayanan publik di Kantor Desa Anabannae Kecamata Pitu Riawa Kabupaten Sidenreng Rappang.

2. HO : profesionalisme kerja aparat berpengaruh/signifikan terhadap kualitas pelayanan publik di Kantor Desa Anabannae Kecamata Pitu Riawa Kabupaten Sidenreng Rappang.

Pengambilan Keputusan :
1. Jika nilai $t$ hitung $\geq t$ tabel, maka $\mathrm{HO}$ ditolak dan Ha diterima, artinya Signifikan

2. Jika nilai $t$ hitung $\leq t$ tabel, maka $\mathrm{HO}$ diterima dan $\mathrm{Ha}$ ditolak, artinya tidak Signifikan

Tabel Coefficients diperoleh $\mathrm{t}$ hitung $=$ 9.574 prosedur mencari statistic tabel dengan kriteria

1. Tingkat signifikan $(a=0,05)$

2. $\mathrm{df}=$ Jumlah Responden -2 atau $92-2=90$

$$
\text { 3. } \begin{aligned}
\mathrm{t} \text { tabel } & =\mathrm{a} / 2 ; \mathrm{df} \\
= & 0,05 / 2 ; \mathrm{df} \\
= & 0,025 ; 90
\end{aligned}
$$

Sehingga $\mathrm{t}$ tabel $=0.2050$

Keputusan :

Ternyata nilai $\mathrm{t}$ hitung $>\mathrm{t}$ tabel atau $9.574>0.2050$, maka $\mathrm{HO}$ ditolak dan $\mathrm{Ha}$ diterima, artinya signifikan. Jadi, profesionalisme kerja aparat berpengaruh signifikan terhadap kualitas pelayanan publik di Kantor Desa Anabanae Kecamata Pitu Riawa Kabupaten Sidenreng Rappang.

Berdasarkan keputusan yang telah dipaparkan tentang pengujian hipotesis dapat dijelaskan bahwa Ha diterima dan Ho ditolak dengan kata lain $t$ hitung $>t$ tabel $(9.574>$ 0.2050), maka HO ditolak dan Ha diterima, artinya signifikan. Jadi, profesionalisme kerja aparat berpengaruh signifikan terhadap kualitas pelayanan publik di Kantor Desa Anabanae Kecamata Pitu Riawa Kabupaten Sidenreng Rappang. Hasil penelitian ini secara teoretis sejalan dengan (Pamudji 1994:22) yang menyatakan bahwa seseorang yang tergolong profesionalisme, yang memiliki atau dianggap memiliki keahlian, akan melakukan kegiatan-kegiatan (pekerjaan) diantaranya pelayanan publik yang lebih baik kualitas, lebih cepat prosesnya, mugkin lebih bervariasi, yang kesemuanya mendatangkan kepuasa pada warga masyarakat.

Kinerja aparat yang profesional akan meningkat kualtas pelayanan publik yang ada di Kantor Desa Anabannae, Hal ini sejalan dengan teori yang dikemukakan oleh Pamudji (1994:30) menyerahkan bahwa "sedini mungkin pemrintah menguasahakan profesionalisme aparaturnya dan sedapat mungkin juga meningkatkan profesionalisme. Walaupun harus diakui, bahwa profesionalisme aparatur bukan satu-satunya jalan untuk meningkatkan pelayanan publik, karena masih ada alternatif lain. Dengan demikian dapat disimpulkan bahwa semakin 
tinggi tingkat profesionalisme pegawai, akan semakin baik dan meningkat pula kualitas pelayanan diberikan kepada masyarakat pengguna jasa (publik), khusunya mereka yang membutuhkan pelayanan jasa melalui pegawai.

Berdasarkan data distribusi frekuensi variabel profesionalisme dapat dilihat bahwa tingkat capaian responden sebesar $59,6 \%$ berkategori kurang baik maka dari itu bagian dari profesionalisme harus tetap ditingkatkan seperti persamaan, keadilan, kedisiplinan dan tanggungjawab. Berdasarkan penelitian yang telah dilakukan tingkat capaian responden yang paling tinggi adalah indikator tanggung jawab dengan presentase sebesar $62,2 \%$, Hal ini dilihat berdasaarkan kinerja aparat dalam melaksanakan tugas administrasi di Kantor sesuai dengan apa yang dibutuhkan masyarakat. Sedangkan tingkat capaian responden yang paling rendah adalah keadilan dengan presentase sebesar $58 \%$ karena aparat desa tidak berlaku adil kepada masyarakat seperti memberikan pelayanan umum.

Data disritbusi frekuensi variabel kualitas pelayanan publik dapat dilihat bahwa tingkat capaian responden yang diberikan pemerintah kepada masyarakat adalah $59,16 \%$ yang terdiri dari 6 indikator pelayanan publik yang dinyakan oleh Lijan Poltak Sinambela (2008:6) diantaranya a) transparansi yaitu sikap keterbukaan aparat Desa Anabannae Kecamatan Pitu Riawa kepada masyarakat yang membutuhkan pelayanan b) akuntabilitas yaitu sikap tangunggjawab aparat Desa Anabannae Kecamatan Pitu Riawa terhadap pelayanan yang diberikan kepada seluruh masyarakat, c) kondisional yaitu sikap peduli aparat Desa Anabannae Kecamatan Pitu Riawa untuk memahami keadaan setiap masyarakat, d) partisipasi yaitu aparat Desa Anabannae mengikutsertakan masyarakat dalam setiap pengambilan keputusan, e) kesamaan hak yaitu kemampuan aparat Desa Anabannae untuk berbuat adil kepada masyarakat, serta f) keseimbangan hak dan kewajiban yaitu kemampuan aparat Desa Anabannae menyeimbangkan antara tugas dan kepentingan pribadi. Adapun indikator yang tertinggi dalam kualitas pelayanan publik adalah transparansi presentase $64,4 \%$ berkategori sangat baik, Hal ini dibuktikan dengan cara aparat desa memberikan pelayanan administrasi yang terbuka terkait
p-ISSN 2302-6960

e-ISSN 2716-165X

dengan apa yang dibutuhkan oleh masyarakat di Kantor Desa Anabannae adapun indikator paling rendah dalam variabel ini adalah kondisional dengan tingkat capaian presentasi sebesar $55,8 \%$, Hal ini dibuktikan dengan aparat desa yang tidak memahami kondisi masyarakat saat memerlukan pelayanan di Kantor Desa Anabannae.

Hasil analisis data faktor yang mempengaruhi profesionalisme

kerja aparat terdiri dari 5 indikator

kemahiran, b) kesiapan, c)tanggung jawab,d) disiplin,dan e) sikap pegawai. Berdasarkan penelitian yang telah dilakukan tingkat capaian responden yang paling tinggi adalah kemahiran dengan tingkat capaian responden sebesar $61,2 \%$, Hal ini dilihat berdasarkan sikap disiplin aparat dalam memberikan pelayanan kepada masyarakat. Sedangkan tingkat capaian responden yang paling rendah adalah kesiapan, Hal ini dilihat berdasarkan kemampuan aparat menjalankan tugasnya dengan baik kepada masyarakat.

Berdasarkan hal tersebut, maka pelayanan publik dikatakan profesional apabila dalam menjalankan tugas aparat desa mampu menerapkan prinsip profesionalime kerja diantara persamaan, keandilan, kedisiplinan dan tanggung jawab di Kantor Desa Anabannae sehingga mampu meningkatkan kepuasan masyarakat dalam pemberian pelayanan.

\section{KESIMPULAN}

Berdasarkan dengan hasil penelitian dan pembahasan dapat ditarik kesimpulan sebagai berikut :

1. Berdasarkan dari analisis data bahwa Profesionalisme Kerja Aparat terhadap Kualitas Pelayanan Publik di Desa Anabannae Kecamatan Pitu Riawa Kabupaten Sidenreng Rappang dapat dikatakan berpengaruh dan signifikan Berdasarkan hasil perhitungan SPSS versi 21 maka, $t$ hitung $>\mathrm{t}$ tabel atau $9.574>$ 0.2050 , maka $\mathrm{HO}$ ditolak dan Ha diterima, artinya signifikan dengan kategori kurang baik dengan melihat hasil ideal presentase $58 \%$.

2. Faktor-faktor yang mempengaruhi profesionalisme kerja 1). Kemahiran: Pengetahuan dan keterampilan yang diper oleh dari pendidikan dan pelatihan serta pengalaman aparat di Kantor Desa 
Anabannae 31,4\%. 2). Kesiapan:

Kemampuan aparat di Kanttor Desa Anabannae dalammemberikan pelayanan yang cepat dan tepat kepada masyarakat $58,6 \%$. 3). Tangggung jawab Kemampuan aparat di Kantor Desa Anabannae menghubungi masyarakat secepatnya apabila terjadi sesuatu sesuai yang perlu segera diberitahukan 60\%. 4). Kedisplinan: Kemampuan aparat menaati peraturan-peraturan yanga ada di Kantor Desa Anabannae 61,2\%. 5). Sikap Pegawai di Knator Desa Anabannae memiliki keterampilan, sikap dan pengetahuan yang dibutuhkan agara dapat memberikan pelayanan $60.4 \%$. Berdasarkan diatas dapat dijelaskan bahwa masyarakat sebagai responden memberikan tanggapan faktor-faktor yang mempengaruhi profesionalisme kerja yaitu $60.32 \%$ atau dikategorikan kurang baik .

\section{E. DAFTAR PUSTAKA}

Ahmad Jamaluddin. 2015. Metode Penelitian Administrasi Publik. Gava Media:Yogyakarta.

Ghozali, Imam. 2009. "Aplikasi Multivariate dengan Program SPSS". Semarang:UNDIP

Mukarom, Zaenal, \& Laksana, Muhibudin Wijaya. 2016. Membangun Kinerja Pelayanan Publik Menuju Clean Government And Good Governance. Bandung.

Nazir, Muhammad. Metode Penelitian. Jakarta:Ghalia Indonesia.

Sellang, Kamaruddin. 2016 : 76 Administrasi \& Pelayanan Publik Antara Teori \& Aplikasi. Ombak: Yokgyakarta.

Samad,. 2016. Birokrasi Dalam Pelayanan Publik. Ombak, Yokgyakarta.

Sellang Kamaruddin, 2016. Administrasi \& Pelayanan Publik Antara Teori \& Aplikasi, Ombak, Yokyakarta.

Sugiyono. 2015. Metode Penelitian Pendidikan( Pendekatan Kuantitatif, Kualitatif, R\&D).

$\begin{array}{ccc}\text { Sedarmayanti, } & 2003 . & \text { Dasar-Dasar } \\ \text { Pengetahuan } & \text { Tentang } & \text { Manajemen }\end{array}$
p-ISSN 2302-6960

e-ISSN 2716-165X

Perkantoran. Mandar Maju : Bandung.

Ibrahim, M. (2014). Profesionalisme Pegawai Negeri Sipil Dalam Pelayanan Publik Pada Kantor Terpadu Satu Pintu Kabupaten Sidenreng Rappang. 427436.

Thoha, Miftah .2001. Perilaku Organisasi : Konsep dan Aplikasinyo, Jakarta : Raja Grafindo Persade..

\section{Dokumen}

Undang-undang Nomor 25 Tahun 2009 tentang Pelayanan Publik 